\title{
Professional Perceptions of Green Roof and its Potential in Malaysian Market
}

\author{
Syumi Rafida Abdul Rahman, Hamidah Ahmad, \\ Muhamad Solehin Fitry Rosley \\ Faculty of Built Environment, \\ Universiti Teknologi Malaysia, Malaysia \\ 1'syumirafida@gmail.com
}

\begin{abstract}
This paper discusses the perceptions towards green roof among Malaysian professionals in built environment industry and its potential in the country's market. A total of 30 projects of local green roofs has been identified and used in this study. Online survey is used as a tool to get feedback from the professionals in the construction discipline, the landscape architect, architect, developer, government officer, urban planner, project executive and also academicians. Based on the findings, most of the professionals perceived that a green roof is beneficial to apply in order to sustain the country development in the future.
\end{abstract}

Keywords: Green roof; professional involvement; perception; green roof market

eISSN 2398-4295 @ 2018. The Authors. Published for AMER ABRA cE-Bs by e-International Publishing House, Ltd., UK. This is an open-access article under the CC BY-NC-ND license (http://creativecommons.org/licenses/bync-nd/4.0/). Peer-review under responsibility of AMER (Association of Malaysian Environment-Behaviour Researchers), ABRA (Association of Behavioural Researchers on Asians) and cE-Bs (Centre for EnvironmentBehaviour Studies), Faculty of Architecture, Planning \& Surveying, Universiti Teknologi MARA, Malaysia.

DOI: http://dx.doi.org/10.21834/ajbes.v3i10.87 


\subsection{Introduction}

Global warming is a major disaster occurred in the 21st century. Almost all part of the world are inseparable from suffering the effects of global warming phenomenon. Global warming is a result from environmental issues such as urban heat island, increase in energy demands, air pollution and lack of green spaces in urbanized area. In Malaysia, the most crucial environmental issues usually occur in Kuala Lumpur, Pulau Pinang and Johor Bahru. However, Malaysia is targeting to decrease $40 \%$ of released carbon dioxide until 2020 (Anandaraj, 2011). In order to achieve the target, the government established Malaysia Green Technology Corporation (GreenTech Malaysia), enactment of legal mechanisms to regulate and enforce green technology. Moreover, the role of every government agency involved in the implementation of green technology in the country is also emphasized. Apart from that, the Ministry of Energy, Green Technology and Water (KeTTHA) take an initiatives by organizing the region's largest green technology exhibition and conference, International GreenTech and Eco Products Exhibition and Conference Malaysia (IGEM) every year since 2010 (3rd IGEM, 2012).

\subsection{Literature Review}

Green roof is one of the approaches of green technology. Green roof is defined as a vegetated system where plants are planted on the roof using an engineered growing medium laid on certain layers of the system (Tan, 2008; Dunnett et. al, 2011). As the green roof is originally from four-season countries, the climate differs from Malaysia. Therefore, there are various attitudes and reaction towards the technology among the professionals in built environment industry (Rahman et. al, 2013). Therefore, study on the perceptions of green roof must be done in order to understand the current level of understanding and potential market rate of green roof implementation in the country. Result of the study is crucial as professionals in built environment industry are the responsible party to determine the success of green roof in Malaysia. In addition, this study has managed to compile a total of 30 green roof projects throughout the country. The reason for the compilation is to indicate and assess to what extent the implementation of green technology in the country. Thus, the result is a notable finding to be discussed and analysed to determine the direction of future green roof use in Malaysia.

\subsection{Methodology}

\section{Survey Questionnaire}

Survey questionnaire was posted online for 44 days from $21^{\text {st }}$ June 2012 until $2^{\text {nd }}$ August 2012. The professionals were categorized based on their field as shown in Table 1. 
Table 1. Percentage of respondent population size

\begin{tabular}{llcl}
\hline Category & Population size & $\begin{array}{c}\text { Response } \\
(\%)\end{array}$ & Rate \\
\hline Landscape Architect & 37 & 30.8 \\
Architect & 20 & 16.7 \\
Academician & 14 & 11.7 & \\
Developer & 13 & 10.8 \\
Urban Planner & 13 & 10.8 \\
Government Officer & 12 & 10.0 \\
Project Executive & 11 & 9.2 \\
\hline
\end{tabular}

The number of professionals in accordance to their respective fields is unequal. Based on the findings, the higher populations of respondent's group are the professionals in the Landscape Architecture discipline with $30.8 \%$ of the responses. The lowest population is the Project Executive with $9.2 \%$ responses.

\section{Survey Form}

There are total 11 questions in the survey form; 4 are open-ended questions while the rest are close-ended. The questionnaire consists of three sections. The first section of the survey questionnaire was designed to identify and categorized respondents' discipline. This section aims to determine respondents' familiarity with a green roof and to detect the implementation of green roof in any of their previous projects.

In section two, there are three questions formulated to identify the level of awareness towards green roof among the professionals. Respondents were also asked to indicate any local green roof projects in Malaysia for the purpose of compiling a green roof projects list.

The final section of the survey questionnaire consists of four questions depicting respondent opinion on the potential market for green roof technology implementation in the country.

\subsection{Results and Discussions}

\section{Professional familiarity with green roof}

From the survey, all respondents (100\%) have heard about green roof, and $57.5 \%$ has used the technology in their previous projects. Table 2 indicates the response rate for each group of professionals and the number of respondents who have implemented green roof system in their projects.

There are 69 professionals who have implemented green roof system in their projects. However, only 28 professionals give the name of the undertaken green roof projects. This situation may due to the professionals wanting to keep the information confidential. Therefore, only 30 green roof projects were noted from the survey and sorted according to its building category. Table 3 indicates the category of building undertaken with green roofs projects by the 28 professional and the types of building under each category. 
Table 2. Percentage of professionals who implemented green roof projects

\begin{tabular}{llccc}
\hline Category & Population size & $\begin{array}{c}\text { Number } \\
\text { Responded }\end{array}$ & $\begin{array}{c}\text { Response } \\
(\%)\end{array}$ & Rate \\
\hline Landscape Architect & 37 & 34 & 81.1 \\
Architect & 20 & 16 & 80.0 & \\
Academician & 14 & 0 & 0 & \\
Developer & 13 & 12 & 92.3 & \\
Urban Planner & 13 & 0 & 0 \\
Government Officer & 12 & 0 & 63.6 \\
Project Executive & 11 & 7 & 57.5 \\
\hline Total & 120 & 69 & \\
\hline
\end{tabular}

Table 3. Category of buildings and types of building undertaken with green roof projects

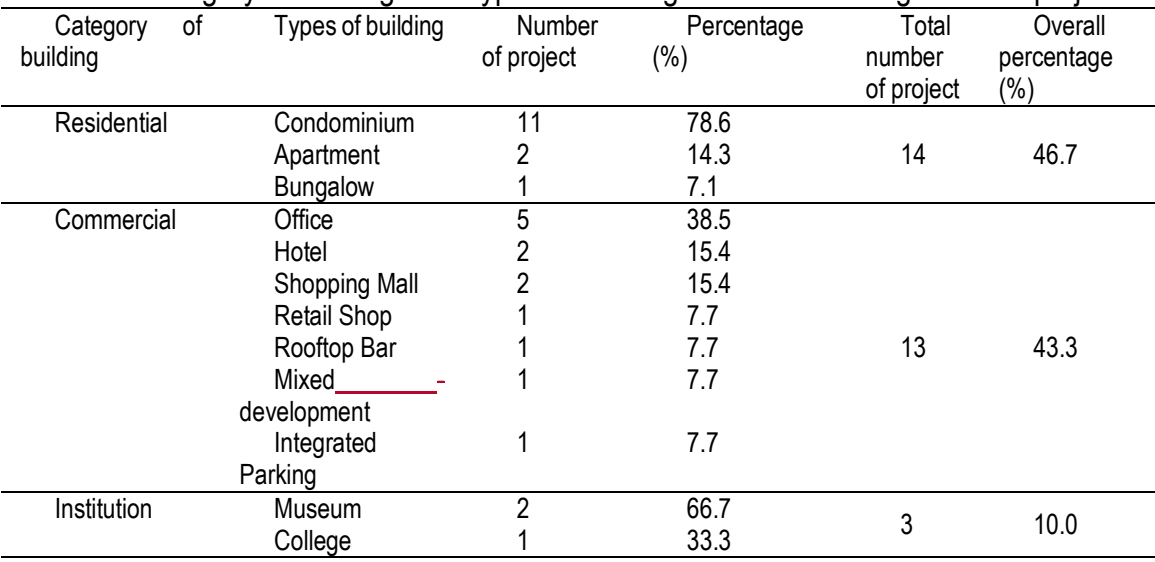

Based on the findings, there are three categories of buildings undertaken with green roofs projects in the country. The most popular building category is residential buildings $(46.7 \%)$ while there are few green roof projects under the category of institutional buildings $(10 \%)$. Many professionals implemented green roof on residential building because, in their opinion, today's societies lack awareness and sense of appreciation for public greenery. Thus, it may cause green roof to be abandoned and vandalized if the design is open public access. Therefore, implementing green roof system and integrating it at residential building may be more reasonable as the green roof will be for private use. The professionals also believe that private designed green roofs are easier to monitor and maintain as the expenses can be outsourced by the residents of the condominium. Another assumption is due to the higher demands of urban dwellers to have their garden in their homes instead of going to a nearby park. The residents may demand to have a sense of ownership by having a garden that could be accessed within a few minute walk from their homes. This concept of living may be one of the factors derived by most of the professionals in implementing green roof systems in the design layout of a residential building. There are three types of residential building. They are condominium, apartment, and bungalow. The most common type of residential 
building with green roof projects are condominium $(78.6 \%)$ while the least is bungalow (7.1\%).

There are five types of commercial buildings whereby professionals implemented green roof projects. The details of the types of buildings is in Table 4. For commercial building, office $(38.5 \%)$ is the most common building with green roof projects while fewer $(7.7 \%)$ retail shop, rooftop bar, mixed-development and integrated parking use a green roof. The use of green roofs on office building may be due to the high demand from corporate building owners as they acknowledge the positive impacts of the systems in increasing the building property value. The reason may also be due to the current trend in central business district (CBD) area where most of the office building owners would like to participate and show their commitment in supporting the green agenda in Malaysia. Apart from that, besides aesthetical values, green roofs can also be a long term investment which can benefit the owner in the long run.

Museum (66.7\%) is the common institutional building having green roof projects among the category of institutions. This is because the designed green roof area within the museum can attract more visitors as it enhances the building uniqueness. Moreover, the return income benefits through the entrance fees of the museum can be used as funds to maintain a green roof. Thirty green roofs projects are recorded successfully from the survey, and the details are in Table 4.

Table 4. Compilation of thirty green roofs project in Malaysia

\begin{tabular}{|c|c|c|c|c|c|c|}
\hline $\begin{array}{l}\text { Green roof } \\
\text { Project }\end{array}$ & Location & $\begin{array}{l}\text { Type of } \\
\text { green roof }\end{array}$ & $\begin{array}{l}\text { Type of } \\
\text { building }\end{array}$ & Level & Accessibility & $\begin{array}{l}\text { Completion } \\
\text { Year }\end{array}$ \\
\hline $\begin{array}{l}\text { Islamic Art } \\
\text { Museum }\end{array}$ & $\begin{array}{l}\text { Tasik } \\
\text { Perdana, } \\
\text { Kuala } \\
\text { Lumpur. }\end{array}$ & Extensive & Museum & One & $\begin{array}{l}\text { Public } \\
\text { access }\end{array}$ & 1998 \\
\hline $\begin{array}{l}\text { Secret } \\
\text { Garden }\end{array}$ & $\begin{array}{l}\text { Bandar } \\
\text { Utama, } \\
\text { Kuala } \\
\text { Lumpur. }\end{array}$ & Intensive & $\begin{array}{l}\text { Shopping } \\
\text { mall }\end{array}$ & Seventh & \begin{tabular}{l}
\multicolumn{1}{c}{ Public } \\
access (but \\
on weekend \\
only)
\end{tabular} & 2007 \\
\hline $\begin{array}{l}\text { Menara } \\
\text { Mesiniaga }\end{array}$ & $\begin{array}{l}\text { Subang } \\
\text { Jaya, } \\
\text { Selangor. }\end{array}$ & Extensive & Office & $\begin{array}{l}\text { First level of } \\
\text { the } \\
\text { extended } \\
\text { roof area. }\end{array}$ & $\begin{array}{c}\text { Non- } \\
\text { accessible }\end{array}$ & 1992 \\
\hline $\begin{array}{l}\text { Oasis Ara } \\
\text { Aquare }\end{array}$ & $\begin{array}{l}\text { Damansara, } \\
\text { Selangor. }\end{array}$ & Extensive & Retail shop & Second & Accessible & 2009 \\
\hline Kiara 9 & $\begin{array}{l}\text { Mont Kiara, } \\
\text { Kuala } \\
\text { Lumpur. }\end{array}$ & Intensive & Condominium & $\begin{array}{l}\text { Three and a } \\
\text { half (consist } \\
\text { of } 16 \\
\text { gardens) }\end{array}$ & $\begin{array}{l}\text { Private } \\
\text { access }\end{array}$ & 2011 \\
\hline $\begin{array}{l}\text { Casa Desa } \\
\text { Condominium }\end{array}$ & $\begin{array}{l}\text { Taman } \\
\text { Desa, Kuala } \\
\text { Lumpur. }\end{array}$ & Intensive & Condominium & Third & $\begin{array}{l}\text { Private } \\
\text { access }\end{array}$ & 2008 \\
\hline The Saffron & $\begin{array}{l}\text { Sentul East, } \\
\text { Kuala } \\
\text { Lumpur. }\end{array}$ & Intensive & Condominium & Fourth & $\begin{array}{l}\text { Private } \\
\text { access }\end{array}$ & 2008 \\
\hline $\begin{array}{l}\text { Riana Green } \\
\text { East }\end{array}$ & $\begin{array}{l}\text { Wangsa } \\
\text { Maju, Kuala } \\
\text { Lumpur. }\end{array}$ & Intensive & Condominium & Fourth & $\begin{array}{l}\text { Private } \\
\text { access }\end{array}$ & 2009 \\
\hline
\end{tabular}


Abdul Rahman, S.R., et.al. / Asian Journal of Behavioural Studies (AjBeS), 3(10) Mar / Apr 2018 (p.127-135)

\begin{tabular}{|c|c|c|c|c|c|c|}
\hline The Tamarind & $\begin{array}{l}\text { Sentul East, } \\
\text { Kuala Lumpur }\end{array}$ & Intensive & Condominium & Fourth & Private access & 2006 \\
\hline Menara Binjai & $\begin{array}{l}\text { Ampang, } \\
\text { Kuala } \\
\text { Lumpur. }\end{array}$ & Intensive & Office & $\begin{array}{l}\text { Every third } \\
\text { floor has } \\
\text { access to } \\
\text { garden } \\
\text { terraces, } \\
\text { Sky garden } \\
\text { at thirty two } \\
\text { floors. } \\
\end{array}$ & Private access & 2011 \\
\hline $\begin{array}{l}\text { Rice Museum } \\
\text { (Laman Padi) }\end{array}$ & $\begin{array}{l}\text { Langkawi, } \\
\text { Kedah. }\end{array}$ & Extensive & Museum & First & Public access & 2009 \\
\hline $\begin{array}{ll}\text { Setia } & \text { Eco } \\
\text { Villa } & \end{array}$ & $\begin{array}{l}\text { Shah Alam, } \\
\text { Kuala } \\
\text { Lumpur. }\end{array}$ & Intensive & Bungalow & First & Private access & 2007 \\
\hline $\begin{array}{l}\text { Idaman } \\
\text { Residence }\end{array}$ & $\begin{array}{l}\text { Jalan P. } \\
\text { Ramlee, } \\
\text { Kuala Lumpur }\end{array}$ & Extensive & Condominium & Thirty four & Private access & 2008 \\
\hline $\begin{array}{ll}\text { Balin } & \text { Roof } \\
\text { Garden } & \text { Nak } \\
\text { Hotel } & \\
\end{array}$ & $\begin{array}{l}\text { Sandakan, } \\
\text { Sabah. }\end{array}$ & Intensive & Hotel & Eight & Private access & \\
\hline Zouk Club & Kuala Lumpur & Intensive & Rooftop Bar & & Private access & \\
\hline Lot 10 & Kuala Lumpur & Intensive & Shopping mall & Eight & Public access & \\
\hline Monte Bayu & $\begin{array}{l}\text { Cheras, } \\
\text { Kuala } \\
\text { Lumpur. }\end{array}$ & Intensive & Apartment & Seventh & Public access &. \\
\hline $\begin{array}{l}\text { Park Seven } \\
\text { Condo }\end{array}$ & $\begin{array}{l}\text { Persiaran } \\
\text { KLCC, Kuala } \\
\text { Lumpur }\end{array}$ & Extensive & Condominium & .. & Private access & 2008 \\
\hline $\begin{array}{l}\text { Dataran } \\
\text { Shamelin }\end{array}$ & $\begin{array}{l}\text { Cheras, } \\
\text { Kuala Lumpur }\end{array}$ & Intensive & Office & First & Public access & .. \\
\hline $\begin{array}{l}\text { KLIA covered } \\
\text { integrated } \\
\text { parking }\end{array}$ & $\begin{array}{l}\text { Sepang, } \\
\text { Kuala } \\
\text { Lumpur. }\end{array}$ & Intensive & $\begin{array}{l}\text { Integrated } \\
\text { parking }\end{array}$ & Fifth & Public access & 1998 \\
\hline $\begin{array}{l}\text { Cimb Bank } \\
\text { Menara } \\
\text { Bumiputera } \\
\text { Commerce } \\
\end{array}$ & $\begin{array}{lr}\text { Jalan } & \text { Raja } \\
\text { Laut, } & \text { Kuala } \\
\text { Lumpur. }\end{array}$ & Extensive & Office & First & Non-accessible & \\
\hline $\begin{array}{l}\text { Malaysian } \\
\text { Design } \\
\text { Innovation } \\
\text { Centre }\end{array}$ & $\begin{array}{l}\text { Cyberjaya, } \\
\text { Selangor. }\end{array}$ & Extensive & College & $\begin{array}{l}\text { On top of } \\
\text { low-rise } \\
\text { building }\end{array}$ & Private access & 2004 \\
\hline $\begin{array}{l}\text { Mewah Oil } \\
\text { Headquarters }\end{array}$ & $\begin{array}{l}\text { Port Klang, } \\
\text { Selangor. }\end{array}$ & Intensive & Office & Fourth & Private access & 2003 \\
\hline $\begin{array}{l}\text { Swiss Garden } \\
\text { Residences }\end{array}$ & $\begin{array}{l}\text { Jalan Pudu, } \\
\text { Kuala } \\
\text { Lumpur. }\end{array}$ & Intensive & Apartment & Sixth & Private access & 2011 \\
\hline $\begin{array}{l}\text { Hilton \& Le } \\
\text { Meridien }\end{array}$ & $\begin{array}{l}\text { Jalan Stesen } \\
\text { Sentral, Kuala } \\
\text { Lumpur. }\end{array}$ & Intensive & Hotel & .. & Private access & 2003 \\
\hline $\begin{array}{l}\text { Suasana } \\
\text { Sentral } \\
\text { Condominium }\end{array}$ & $\begin{array}{l}\text { Sentral, } \\
\text { Kuala } \\
\text { Lumpur. }\end{array}$ & Intensive & Condominium & Sixth & Private access & 2002 \\
\hline $\begin{array}{l}\text { Ritze } \\
\text { Perdana 2 }\end{array}$ & $\begin{array}{l}\text { Petaling Jaya, } \\
\text { Selangor. }\end{array}$ & Intensive & $\begin{array}{l}\text { Mixed- } \\
\text { development } \\
\text { (shops and } \\
\text { condominium) } \\
\end{array}$ & Sixth & Private access & 2010 \\
\hline $\begin{array}{l}\text { Perdana } \\
\text { Exclusive }\end{array}$ & $\begin{array}{l}\text { Petaling Jaya, } \\
\text { Selangor. }\end{array}$ & Intensive & Condominium & Fourth & Private access & .. \\
\hline
\end{tabular}


Abdul Rahman, S.R., et.al. / Asian Journal of Behavioural Studies (AjBeS), 3(10) Mar / Apr 2018 (p.127-135)

\begin{tabular}{|l|l|l|l|l|l|l|}
\hline $\begin{array}{l}\text { Green roof } \\
\text { Project }\end{array}$ & Location & $\begin{array}{l}\text { Type of } \\
\text { green roof }\end{array}$ & Type of building & Level & Accessibility & $\begin{array}{l}\text { Completion } \\
\text { Year }\end{array}$ \\
\hline $\begin{array}{l}\text { Flora } \\
\text { Damansara }\end{array}$ & $\begin{array}{l}\text { Petaling Jaya, } \\
\text { Selangor. }\end{array}$ & Intensive & Condominium & Sixth & Private access &.. \\
\hline The Maple & $\begin{array}{l}\text { Sentul West, } \\
\text { Kuala } \\
\text { Lumpur. }\end{array}$ & Intensive & Condominium & Fifth & Private access & 2006 \\
\hline
\end{tabular}

\section{Benefits of having green roofs}

The survey questionnaire also indicates professionals' views on the advantages of having green roof. From the survey, professionals have given 16 advantages of having a green roof. The findings summary are in Table5.

Table 5. Summary of green roof advantages

\begin{tabular}{lll}
\hline Advantages & Number Responded & Response Rate (\%) \\
\hline Urban Heat Island (UHI) mitigation & 72 & 71.3 \\
Aesthetic value & 39 & 38.6 \\
Alternative green area & 29 & 28.7 \\
Save environment & 28 & 27.7 \\
Storm water management & 20 & 19.8 \\
Thermal comfort & 19 & 18.8 \\
Increase Green Mark point & 17 & 16.8 \\
Soften building façade & 17 & 16.8 \\
Educational opportunities & 15 & 14.9 \\
Natural habitat creation & 14 & 13.9 \\
Energy efficiency & 12 & 11.9 \\
Improve air quality & 11 & 10.9 \\
Increase roof life span & 9 & 8.9 \\
Psychology health & 5 & 5.0 \\
Reduce noise & 3 & 3.0 \\
\hline
\end{tabular}

Based on the summary of green roof advantages, majority of the professionals in the built environment industry agree that green roofs could help to mitigate urban heat island (UHI) in the city $(71.3 \%)$ compared to other advantages. Only a minority believe that a green roof could reduce the noise of the city's hustle bustle $(3 \%)$. This may be because the benefit has not been practically studied and proven yet in the Malaysian context. The disparity of views among the professionals is mainly because of the differences of their background knowledge and technical expertise in the industry.

\section{Green roof market in Malaysia}

From the findings, $94 \%$ of the respondents agree that green roofs have potential marketability in the country. The professionals also stated that the general cost uptake for one square meter intensive green roof is RM400 and above while for extensive is around RM300 to RM400. The expensive construction cost for green roof design becomes one of the barriers for the systems implementation in Malaysia. This may due to the lack of green roof expertise and supplier or manufacturer within the country. In other Asian countries which started implementing green roof in mid 2000s, the cost uptake for one square meter of extensive green roof is approximately between RM100 to RM350. In China, the cost for one square 
meter extensive green roof is RM111, in Manila, RM148, and in Hong Kong, the cost is RM320. Singapore started green roof implementation in the early 2000s. However, the cost for one square meter of extensive green roof is similar with Hong Kong, RM320. The cost for one square meter of extensive green roof is much lower in China and Manila compared to Singapore and Malaysia. This may due to the production and manufacturing of most of the materials for green roof are within the country.

The Singapore government initiated incentive schemes to accelerate the growth of green roofs in their country. Therefore, it is possible for Singaporean professionals in the built environment industry to implement the system even though it is expensive. On the other hand, the Malaysian government has started to encourage Malaysian professionals to embrace green technology application in 2009. This effort can be seen through the launching of the National Green Technology Policy with the establishment of the National Green Technology Council in July 2009. Budget 2010 indicated that the Government had allocated RM1.5 billion for companies that supply and utilize green technology through Green Technology Finance Scheme (GTFS). The government also introduces a series of tax incentives that one of them is for Green Building Index (GBI) certified buildings. The incentive scheme provides income tax exemption for the owner of the building and stamps duty exemption for the property buyers according to the specified rules and conditions (Green Tax Incentives for a Sustainable Malaysia, 2010).

\subsection{Conclusion}

Based on the 30 green roof projects from the survey shows that intensive green roof is the most common green roof being constructed in the country. While the common type of building where most designed with intensive green roof is residential. The survey findings suggest that most of the Malaysian professionals in built environment industry are aware of green roof technology. However, due to certain barriers led to less interest to use the system. The barriers including lack of knowledge and technical expert, expensive cost of green roof and green roof application techniques are not widely disseminated or spread among professionals. Therefore, all parties in the industry and government body have the responsibility to promote green roof system as one of the approaches for green technology application in the country. Thus in return, it could help to accelerate the marketability and progress of green roof in the country.

\section{Acknowledgement}

We would like to thank the anonymous reviewer for valuable comments on the paper and also for the thoughtful ideas and encouragement during the writing stage of the paper.

\section{References}

Anandaraj, E. (2011). Green technology. A New Straits Times Special, Malaysia. 
Dunnett, N., Gedge, D., Little, J. \& Snodgrass, E. C. (2011). Small green roofs: Low-Tech options for greener living. Timber Press, Portland, London.

Green tax incentive for a sustainable Malaysia (2010). PwC Alert Issue No. 86, PP9741/10/2010 (025623).

Rahman, S. R. A., Ahmad, H. and Rosley, M. S. F. (2013). Green roof: Its awareness among professionals and potential in Malaysian market. Social and Behavioral Sciences, 85, 443-453.

Tan, P. Y., \& Sia, A. (2008). A selection of plants for green roofs in Singapore (2nd ed.). National Park Board, Singapore.

The Third International Greentech and Eco Products Exhibition and Conference Malaysia (IGEM) (2012). Kuala Lumpur, Malaysia. 